
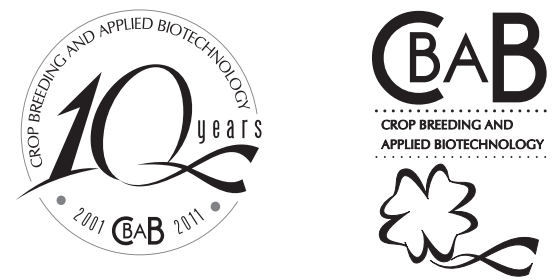

\title{
Reproductive characterization of interspecific hybrids among Capsicum species
}

\author{
Carlos Eduardo da Silva Monteiro ${ }^{1}$, Telma Nair Santana Pereira ${ }^{1 *}$ and Karina Pereira de Campos ${ }^{1 *}$
}

Received 8 June 2010

Accepted 23 September 2010

\begin{abstract}
The objective of this study was the reproductive characterization of Capsicum accessions as well as of interspecific hybrids, based on pollen viability. Hybrids were obtained between Capsicum species. Pollen viability was high in most accessions, indicating that meiosis is normal, resulting in viable pollen grains. The pollen viability of species $\mathrm{C}$. pubescens was the lowest (27 $\%)$. The interspecific hybrids had varying degrees of pollen viability, from fertile combinations (C. chinense $x \mathrm{C}$. frutescens and $\mathrm{C}$. annuum $x \mathrm{C}$. baccatum) to male sterile combinations. Pollen viability also varied within the hybrid combination according to accessions used in the cross. Results indicate that male sterility is one of the incompatibility barriers among Capsicum species since hybrids can be established, but may be male sterile.
\end{abstract}

Key words: Capsicum, wild species, domesticated species, pollen grain, male sterility.

\section{INTRODUCTION}

Interspecific hybridization is important in plant breeding as a tool for gene transfer from one genotype, usually a wild species, to another, cultivated genotype that does not have that gene (Hajjar and Hodgkin 2007). However, the cross between species may be inconsistent or incompatible due to the existence of a set of pre- and post-zygotic barriers (Hogenboom 1973). Pre-zygotic barriers can be, e.g., the absence of pollen grain germination and the delay or inhibition of pollen tube growth. After fertilization, the main barriers are embryonic death due to endosperm degeneration and the total or partial sterility of hybrid plants. These barriers have hindered or prevented the use of the wild species carrying important genes that are absent in the cultivated form in breeding programs; however, tomato breeders have used this tool to develop cultivars as reported by Hajjar and Hodgkin (2007).

The species of the genus Capsicum can be grouped into complexes, each comprising genotypes whose crosses will result in fertile hybrids: the annиum complex, comprising the species $C$. annuum (varieties glabriusculum and annuum), $C$. frutescens, $C$. chinense, $C$. chacoense and $C$. galapagoensis; the baccatum complex composed of the species C. baccatum (varieties baccatum, pendulum and praetermissum) and C. tovari, and the pubescens complex consisting of the species $C$. cardenasii, $C$. eximium and C. pubescens (Pickersgill 1997, Moscone et al. 2006). More recently, other methodologies have been used, such as RAPD markers (Costa et al. 2006) and chloroplast DNA (Ryzhova and Kochieva 2004), where the results have validated the classification of species in gene complexes. The species of the genus are classified into two groups,

\footnotetext{
${ }^{1}$ Universidade Estadual do Norte Fluminense, Centro de Ciências e Tecnologias Agropecuárias, Laboratório de Melhoramento Genético Vegetal, Av. Alberto Lamego 2000, 28.013-602, Campos dos Goytacazes, RJ, Brasil. *E-mail: telmasp@uenf.br
} 
according to the number of chromosomes: one with $2 n=2 x=24$ chromosomes and another with $2 n=2 x=26$ chromosomes. Domesticated species belong to the first group (Moscone et al. 2007, Pozzobon et al. 2006 and Pozzobon and Schifino-Wittmann 2006).

In Capsicum, usually no interspecific hybrids involving species belonging to different gene complexes have been obtained due to some aspects of incongruity, i.e., incompatibility between species, unilateral incompatibility, abortion of the embryo after fertilization and male sterility (Onus and Pickersgill 2004, Pickersgill 1997). Moreover, the more distant two species are genetically, more sterile or unviable their hybrid will be (Singh 1993).

One possible post-zygotic barrier can be hybrid male sterility, which can be measured by the viability of pollen grains in the hybrid combination. The pollen viability is an important indicator of the ability of pollen grains to germinate on the flower stigma and fertilize the egg cell, which is a decisive stage in fertilization (Dafni 1992). Information on pollen viability is essential for studies on the reproductive biology of plant species, allowing the confirmation and understanding of results reported of certain crosses. Pollen viability can be estimated by a number of methods: Lugol solution, Fluorochromatic Reaction (FCR), vital dyes such as tetrazolium salt, germination test in vivo and in vitro and Alexander's solution. According to Alexander (1969), the staining solution is a differential dye that distinguishes viable and unviable pollen grains in most angiosperms, and is considered a quick, cheap and easy technique (Dafni 1992). The distinction by the solution is based on the three dye components: malachite green, acid fuchsin and orange $G$ (Alexander 1969). Malachite green reacts with the pollen grain wall, so the aborted pollen grains are stained green, because they consist of the pollen wall only. Acid fuchsin colors the cytoplasm and mitochondria and its role in this solution is to stain the protoplasm of fertile pollen grains in a color range from red to purple red. Orange $G$ reinforces the differentiation of the above colors, resulting in a clearer distinction between viable and unviable pollen grains (Alexander 1969).

According to Pickersgill (1997) interspecific hybridization has been used frequently in Solanaceae, particularly regarding the transfer of genes for disease and pest resistance; in Capsicum however, the percentage of pollen viability of interspecific hybrids ranges from high to low (Kumar et al. 1987, Lanteri and Pickersgill 1993). According to Shifriss (1997), the degree of male sterility in interspecific Capsicum hybrids depends on the accessions used for each cross. For breeding programs of interspecific hybridization it is therefore essential to evaluate the pollen viability of accessions and hybrids.

This study aimed to characterize the reproductive capacity of interspecific hybrid combinations, obtained by crosses between accessions from domesticated species of Capsicum as well as the reproductive performance of 36 representative accessions of Capsicum species (C. annuum, C. chinense, C. frutescens, C. pubescens, and $C$. baccatum and their botanical forms) based on the pollen viability.

\section{MATERIAL AND METHODS}

Hybrid combinations obtained from artificial pollination among 36 representative accessions of domesticated Capsicum species were evaluated. C. annuиm was represented by 12 accessions ( 10 accessions of $C$. annuum var. anпиит - sweet and hot peppers and two accessions of C. annuum var. glabriusculum - ornamental pepper) (Table 1). The hybrid nature of combinations was validated using molecular as well as phenotypic markers. The accessions and interspecific hybrids were grown in $5 \mathrm{~L}$ pots in greenhouses; 16 hybrid combinations were grown in a greenhouse of a research support unit and 27 at the Experimental Station of Pesagro, Campos dos Goytacazes, RJ. Fertilization and pesticides to control pests and diseases were applied according to the recommendations for the crop (Filgueira 2003).

For the reproductive characterization by pollen viability analysis of the species and hybrids, the flower buds were collected at anthesis and stored in $70 \%$ ethanol solution. Subsequently, the anthers were squashed in drops of Alexander's solution (Alexander 1969). Slides were prepared and examined under an optical microscope (Olympus BX 60, bright field), and the number of viable (purple) and number of unviable pollen grains (green) were counted. Five slides were prepared for each genotype, each representing one anther, where 250 pollen grains/ slide were counted, resulting in a total of 1250 pollen grains per accession. The data were converted into percentage (\%) and the original data were subjected to analysis of variance using software Genes (Cruz 2001) based on a completely randomized design where the slides, five slides/ accession, represented the replicates.

Crop Breeding and Applied Biotechnology 11: 241-249, 2011 
Reproductive characterization of interspecific hybrids among Capsicum species

Table 1. List of the species, accessions/species and general characteristics of the genotypes evaluated

\begin{tabular}{|c|c|c|}
\hline Species & Accessions & General characteristics \\
\hline $\begin{array}{l}\text { C. annuum var annuum } \\
\text { (sweet pepper) }\end{array}$ & $\begin{array}{l}\text { UENF } 1562 \\
\text { UENF } 1565 \\
\text { UENF } 1382 \\
\text { UENF } 1567 \\
\text { UENF } 1569\end{array}$ & $\begin{array}{l}\text { Accessions with upright or intermediate growth habit, flowers with white } \\
\text { corolla and bluish anthers, one flower per axil; yellow seeds. }\end{array}$ \\
\hline $\begin{array}{l}\text { C. annuum var annuum } \\
\text { (hot pepper) }\end{array}$ & $\begin{array}{l}\text { UENF } 1503 \\
\text { UENF } 1381 \\
\text { UENF } 1578 \\
\text { UENF } 1502 \\
\text { UENF } 1575\end{array}$ & $\begin{array}{l}\text { Accessions with upright or intermediate growth habit, flowers with white } \\
\text { corolla and blue anthers; one flower per axil; yellow seeds. }\end{array}$ \\
\hline $\begin{array}{l}\text { C. annuum var grabiusculum } \\
\text { (ornamental pepper) }\end{array}$ & $\begin{array}{l}\text { UENF } 1559 \\
\text { UENF } 1576\end{array}$ & $\begin{array}{l}\text { Accessions with growth habit intermediate, flowers with purple corolla } \\
\text { and purple anthers, at least three flowers per axil; light yellow seeds. }\end{array}$ \\
\hline C. chinense Jacq & $\begin{array}{l}\text { UENF } 1497 \\
\text { UENF } 1498 \\
\text { UENF } 1555 \\
\text { UENF } 1424 \\
\text { UENF } 1585 \\
\text { UENF } 1553\end{array}$ & $\begin{array}{l}\text { Accessions with intermediate growth habit, flowers with light yellow } \\
\text { corolla and blue anthers, three or more flowers per axil; light yellow } \\
\text { seeds. }\end{array}$ \\
\hline C. baccatum var. pendulum & $\begin{array}{l}\text { UENF } 1489 \\
\text { UENF } 1492 \\
\text { UENF } 1496 \\
\text { UENF } 1573 \\
\text { UENF } 1426 \\
\text { UENF } 1490 \\
\text { UENF } 1494 \\
\text { UENF } 1500\end{array}$ & $\begin{array}{l}\text { Accessions with intermediate growth habit, flowers with white corolla } \\
\text { with yellow spots and yellowish anthers; one flower per axil; light yellow } \\
\text { seeds. }\end{array}$ \\
\hline C. baccatum var baccatum & $\begin{array}{l}\text { UENF } 1495 \\
\text { UENF } 1584 \\
\text { UENF } 1417\end{array}$ & $\begin{array}{l}\text { Accessions with upright growth habit, flowers with white corolla with } \\
\text { greenish stripes and blue anthers; three or more flowers per axil; light } \\
\text { yellow seeds. }\end{array}$ \\
\hline C. frutescens & $\begin{array}{l}\text { UENF } 1425 \\
\text { UENF } 1560 \\
\text { UENF } 1561 \\
\text { UENF } 1491 \\
\text { UENF } 1557 \\
\text { UENF } 1588\end{array}$ & $\begin{array}{l}\text { Accessions with intermediate growth habit, flowers with light yellow } \\
\text { corolla and blue anthers, with three flowers per axil; light yellow seeds. }\end{array}$ \\
\hline C. pubescens & UENF 1574 & $\begin{array}{l}\text { Species represented by one accession with flower with purple corolla and } \\
\text { anthers and black seeds. The development of } \mathrm{t} \text { his accession was very } \\
\text { slow. }\end{array}$ \\
\hline
\end{tabular}

\section{RESULTS AND DISCUSSION}

\section{Pollen viability of the accessions}

The distinction of viable (fertile) from nonviable (infertile) pollen grains was performed with high accuracy (Figure 1), which was confirmed by the low coefficient of variation (Table 2). The analysis of variance of pollen viability data showed significant differences between accessions at $1 \%$ probability.

The pollen viability of the botanical forms $C$. аппиит var. aппиит (sweet and hot peppers) and C. аппиит var. glabriusculum (ornamental pepper) was high, with averages ranging from $85.4 \%$ to $97 \%$ (Table 3). The pollen viability of the species $C$. аппиит var аппиит, sweet pepper, was lower (85.4\%) than of the other two forms, mainly because of accession UENF 1569 , with an average of $43 \%$, considered low. According to Pickersgill (2007) domesticated species of Capsicum have a wide range of types, from wild forms, over the cultivated to the completely domesticated forms, except for $C$. pubescens which is only known in the cultivated form. Thus, the low pollen viability of accession UENF 1569 may be due to a 
CES Monteiro et al.

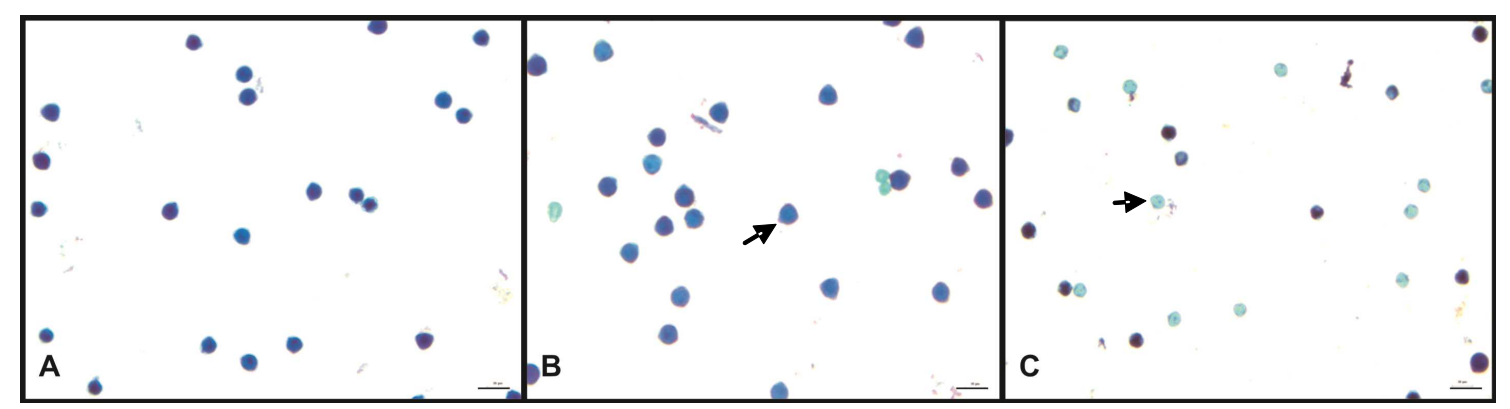

Figure 1. Pollen viability of the hybrid combinations among Capsicum species tested by Alexander's solution. A. Viable pollen grains of the combination C. chinense x C. frutescens; B. Pollen grains of the combination C. chinense x C. annuum var. annuum where viable (arrow) and a few inviable pollen grains can be observed; C. Pollen grains of the hybrid combination C. frutescens $\mathrm{x} C$. baccatum var. pendulum; Arrow indicates inviable pollen grain. $\mathrm{Bar}=30 \mu \mathrm{m}$.

Table 2. Analysis of variance and coefficient of variation $(\mathrm{CV})$ for data of pollen viability of 36 Capsicum accessions

\begin{tabular}{lrcc}
\hline Source of variation & df & Mean squares & F \\
\hline Genotype & 35 & 1326.72 & $29.77^{* *}$ \\
Error & 144 & 44.56 & \\
Total & 179 & & \\
\hline CV (\%) & 7.3 & & \\
\hline
\end{tabular}

${ }^{* *}$ Significant at $1 \%$ probability.

problem of adaptation or due to the presence of some male sterility gene, as is well documented in the literature for C. annuum (Shifriss 1997).

The pollen viability of C. annuum var. annuum (hot pepper) and $C$. annuum var. glabriusculum was high, on average 90.8 and $97 \%$, respectively. The pollen viability of $C$. chinense was also high $(98 \%)$. Capsicum frutescens also had high pollen viability ( $86.8 \%$ ), with the exception of the accessions UENF 1560 and UENF 1588, which had intermediate mean values of, respectively, $60 \%$ and $77 \%$ (Table 3).

The pollen viability of Capsicum baccatum and its botanical forms (var. baccatum and var. pendulum) were high, on average $98.3 \%$ and $96.1 \%$, respectively, and highest for accession UENF 1417, with $100 \%$ viability, indicating that these accessions have a normal meiosis and are therefore well-adapted to the environment where they were grown.

As expected, the pollen viability of Capsicum pubescens was very low (27\%), since this species was originated in the Andean region, with a natural environment of high altitude and low temperatures (Pickersgill 1997, 2007), in contrast to the conditions in the region where the study was conducted.
In general, the pollen viability of Capsicum accessions was high. This finding indicates that the non-formation of fruit or the formation of seedless fruits observed in some interspecific crosses established and described in the literature cannot be attributed to pollen viability.

\section{Pollen viability of the hybrid combinations}

The analysis of variance of the data of pollen grain viability differed significantly among interspecific hybrids (Table 4), which can best be observed by the means of pollen viability of each hybrid combination (Table 5).

The percentage of pollen viability of the hybrids between the species $C$. annuum var. annuит $\mathrm{x} C$. chinense (Figure 1) was low (56\%). This was due to the fact that the pollen viability in some combinations (UENF $1503 \times \mathrm{UENF}$ 1555 ) was very low (34\%) while the reciprocal combination had a high mean viability ( mean $=87 \%$ ). Kumar et al. (1987) observed a pollen viability of $42 \%$ in a hybrid between $C$. annuum x $C$. chinense; a cytological analysis showed that the hybrid $C$. annuum differs from $C$. chinense by two translocations and some minor structural chromosome changes, leading to partial hybrid sterility. Lanteri and Pickersgill (1993) reported that pollen viability of $C$. annuum $\mathrm{x} C$. chinense hybrids ranged from 13 to $16 \%$ and observed that during meiosis the hybrid accessions used in the study differed by two translocations. They also found that the translocations involved three rather than four chromosome pairs, since hexavalent associations were observed in the hybrids, ie, the same chromosome was common to the two independent translocations. According to the authors it is interesting to identify chromosomes that are involved in more than one translocation since sterility associated with heterozygous translocation can prevent gene introgression in Capsicum breeding 
Reproductive characterization of interspecific hybrids among Capsicum species

Table 3. Mean pollen viability of the representative accessions of the five domesticated Capsicum species

\begin{tabular}{|c|c|c|}
\hline Species & Accession & Pollen viability (\%) \\
\hline C. annuum var annuum & UENF 1562 & 97 \\
\hline \multirow[t]{4}{*}{ (sweet pepper) } & UENF 1565 & 99 \\
\hline & UENF 1382 & 89 \\
\hline & UENF 1567 & 99 \\
\hline & UENF 1569 & 43 \\
\hline Mean & & 85.4 \\
\hline C. annuит var annuит & UENF 1503 & 96 \\
\hline \multirow[t]{4}{*}{ (hot pepper) } & UENF 1381 & 98 \\
\hline & UENF 1578 & 98 \\
\hline & UENF 1502 & 69 \\
\hline & UENF 1575 & 93 \\
\hline Mean & & 90.8 \\
\hline C. annuum var grabiusculum & UENF 1559 & 96 \\
\hline (ornamental pepper) & UENF 1576 & 98 \\
\hline Mean & & 97.0 \\
\hline \multirow[t]{6}{*}{ C. chinense Jacq } & UENF 1497 & 99 \\
\hline & UENF 1498 & 96 \\
\hline & UENF 1555 & 99 \\
\hline & UENF 1424 & 98 \\
\hline & UENF 1585 & 98 \\
\hline & UENF 1553 & 99 \\
\hline Mean & & 98.2 \\
\hline \multirow[t]{8}{*}{ C. baccatum var. pendulum } & UENF 1489 & 95 \\
\hline & UENF 1492 & 98 \\
\hline & UENF 1496 & 99 \\
\hline & UENF 1573 & 94 \\
\hline & UENF 1426 & 98 \\
\hline & UENF 1490 & 96 \\
\hline & UENF 1494 & 93 \\
\hline & UENF 1500 & 96 \\
\hline Mean & & 96.1 \\
\hline \multirow[t]{3}{*}{ C. baccatum var baccatum } & UENF 1495 & 97 \\
\hline & UENF 1584 & 98 \\
\hline & UENF 1417 & 100 \\
\hline Mean & & 98.3 \\
\hline \multirow[t]{6}{*}{ C. frutescens } & UENF 1425 & 96 \\
\hline & UENF 1560 & 60 \\
\hline & UENF 1561 & 98 \\
\hline & UENF 1491 & 94 \\
\hline & UENF 1557 & 96 \\
\hline & UENF 1588 & 77 \\
\hline Mean & & 86.8 \\
\hline C. pubescens & UENF 1574 & 27 \\
\hline DMS & & 8.4 \\
\hline
\end{tabular}

programs (Tanksley 1984). These results were not expected since the species belong to the same gene complex. However, according to Carputo (1999), similar problems occur in interspecific crosses of tomato and potato, both of the Solanaceae, as Capsicum. These results are interesting because they suggest that in this type of combination, $C$. chinense should be used as female parent to obtain good hybrid fertility.
Good pollen viability ( $81.5 \%-84 \%)$ was observed in the hybrid combination of $C$. аnnuum var. annuиm $\mathrm{x}$ C. frustescens, and when C. апnuum var. annuum was used as female parent, the pollen viability was slightly lower than of the reciprocal combination, with $95 \%$ of viable pollen grains.

Hybrids between the species $C$. chinense x $C$. frustescens resulted in high pollen viability (Figure 1), of 
CES Monteiro et al.

Table 4. Analysis of variance of pollen viability data of the 45 hybrid combinations of Capsicum

\begin{tabular}{|c|c|c|c|c|c|c|}
\hline \multirow{2}{*}{ Source of variation } & \multicolumn{2}{|c|}{ df } & \multicolumn{2}{|c|}{ Mean squares } & \multicolumn{2}{|c|}{$\mathbf{F}$} \\
\hline & $\mathrm{UAP}^{1}$ & $\mathrm{PESAGRO}^{2}$ & UAP & PESAGRO & UAP & PESAGRO \\
\hline Genotype & 15 & 26 & 4.176 .409 & 4081.58 & $287.73 * *$ & $663.90 * *$ \\
\hline Error & 64 & 108 & 14.515 & 6.15 & & \\
\hline Total & 79 & 134 & & & & \\
\hline CV (\%) & 5.9 & 4.1 & & & & \\
\hline
\end{tabular}

** Significant at $1 \%$ probability.

${ }^{1}$ Unidade de Apoio à Pesquisa (UAP) and ${ }^{2}$ PESAGRO, Campos dos Goytacazes-RJ.

Table 5. Pollen viability (PV) of hybrid combinations among domesticated Capsicum species

\begin{tabular}{|c|c|c|}
\hline Hybrid combination $\left(\stackrel{+}{x} \diamond^{\urcorner}\right)$ & Cross & PV (\%) \\
\hline \multirow[t]{3}{*}{ C. annuum var. annuum $x$ C. chinense } & UENF1578 X UENF 1553 & 47.0 \\
\hline & UENF1503 X UENF 1555 & 34.0 \\
\hline & UENF1575 X UENF 1555 & 87.0 \\
\hline C. chinense $x$ C. annuum var. annuum & UENF1555 X UENF 1503 & 87.0 \\
\hline \multirow{2}{*}{ C. annuum var. annuum $\mathrm{x} C$. frutescens } & UENF1569 X UENF1557 & 81.5 \\
\hline & UENF1503 X UENF1425 & 84.0 \\
\hline C. frutescens $x$ C. annuum var. annuum & UENF1425 x UENF1565 & 95.0 \\
\hline C. chinense $x$ C. frutescens & UENF1585 x UENF1557 & 94.0 \\
\hline \multirow[t]{2}{*}{ C. frutescens $x$ C. annuum var. glabriusculum } & UENF1425 x UENF1573 & 28.0 \\
\hline & UENF1425 x UENF1490 & 26.0 \\
\hline \multirow[t]{4}{*}{ C. annuum var annuum $x$ C. baccatum var pendulum } & UENF1565 x UENF1489 & 96.0 \\
\hline & UENF1381 x UENF1489 & 96.0 \\
\hline & UENF1567 x UENF1573 & 93.0 \\
\hline & UENF1578 x UENF1573 & 92.0 \\
\hline \multirow[t]{3}{*}{ C. baccatum var pendulum $\times$ C. annuum var annuum } & UENF1496 x UENF1562 & 36.0 \\
\hline & UENF1495 x UENF1575 & 36.0 \\
\hline & UENF1584 x UENF1562 & 34.0 \\
\hline \multirow[t]{3}{*}{ C. baccatum var. pendulum x C. annuum var. annuum } & UENF1496 x UENF1562 & 36.0 \\
\hline & UENF1495 x UENF1575 & 36.0 \\
\hline & UENF1584 x UENF1562 & 34.0 \\
\hline \multicolumn{3}{|l|}{ C. baccatum var. baccatum x C. annuum var. annuum } \\
\hline & UENF1495 x UENF1575 & 36.0 \\
\hline \multirow[t]{2}{*}{ C. baccatum var. pendulum x C. annuum var. glabriusculum } & UENF1584 x UENF1562 & 34.0 \\
\hline & UENF1500 x UENF1576 & 32.0 \\
\hline C. baccatum var. pendulum $\times$ C. chinense & UENF1573 x UENF1555 & 25.0 \\
\hline \multirow[t]{4}{*}{ C. baccatum var. pendulum $\times$ C. frutescens } & UENF1489 x UENF1561 & 46.0 \\
\hline & UENF1492 x UENF1425 & 53.0 \\
\hline & UENF1496 x UENF1561 & 49.6 \\
\hline & UENF1489 x UENF1560 & 54.5 \\
\hline C. frutescens $\mathrm{x}$ C. baccatum var. pendulum & UENF1425 x UENF1573 & 15.5 \\
\hline
\end{tabular}

around $94 \%$, confirming that these two species are compatible and produce fertile hybrids, so a gene transfer between the two species is possible. Unfortunately, no reciprocal hybrids were obtained, but these two species are considered genetically very close, since 12 bivalent pairs were observed in interspecific hybrids (Shifriss 1997). 
C. annuum and C. baccatum are considered species belonging to different gene complexes in view of the crossability. However, fertile hybrids were obtained between the species $C$. апnиum var. annuum (sweet or hot pepper) and C. baccatum var pendulum with pollen viability exceeding $90 \%$ (Table 4 ). On the other hand, the viability of the reciprocal combinations was low, around $35 \%$, and combinations between $C$. baccatum var. baccatum $\mathrm{x} C$. annuum var. annuum resulted in hybrids with very low fertility as well (Table 5), with an average $35 \%$ of viable pollen grains. C. annuиm and $C$. baccatum belong to different gene complexes, and the results reported here were not expected. An interesting observation was the high pollen viability when $C$. аnnuum was used as female parent, since the pollen viability of such combinations was high. According to Shifriss (1997), hybrids between C. annuum and C. baccatum have varying degrees of male sterility, according to the accession used in the interspecific cross.

Kumar et al. (1987) estimated a pollen viability of around $42.6 \%$ for the interspecific hybrid between C. annuum var cerasiforme $\mathrm{x}$ C. baccatum var. pendulum, and concluded that the two species differed by two translocations, one inversion and some small chromosomal changes and that the barriers between the two species are expressed in the hybrid fragility and the occurrence of chromosome desynapsis in the hybrid, once the occurrence of desynaptic genes was reported in C. апnиum var. cerasiforme (Panda et al. 1987). Egawa and Tanaka (1986) however reported very low pollen viability (around $6.5 \%$ ) of the hybrid combination between $C$. апnиит var minimum x $C$. baccatum var. baccatum.

In the hybrid combinations $C$. baccatum var. pendulum $\mathrm{x} C$. chinense and C. baccatum var. pendulum $\mathrm{x} C$. annuum var glabriusculum the pollen viability was very low (25\% and $32 \%$, respectively). The combinations $C$. baccatum var. pendulum x C. frutescens varied in pollen viability (from $54.5 \%$ to $46 \%$ ), which was considered low, indicating partial male sterility of these hybrids. Bapa Rao et al. (1992) estimated pollen viability ranging from 23.6 to $25.4 \%$ in a hybrid combination involving the two above species. According to the authors the main factors of hybrid sterility were sterility genes, heterozygous translocations, and meiotic behavior with segregation anomalies. The same authors reported difficulty in the establishment of the reciprocal combination, which were not obtained even after repeated artificial pollinations. In this study the reciprocal combination between the two species was achieved, but the pollen viability was very low (Figure 1), indicating a male sterile combination, confirming the data of the other authors.

The pollen viability of the hybrid combination C. frutescens x C. annuum var. glabriusculum was also very low (Table 5), less than $30 \%$, indicating problems of chromosome homology between these species; this result was rather unexpected as the species belong to the same gene complex. However, C. frutescens carries mitochondrial genes for male sterility (Shifriss 1997), so it is possible that the hybrid will show varying degrees of male sterility in all combinations involving this species as female parent.

Generally speaking, the hybrid pollen viability ranged from very low values, suggesting complete male sterility, to intermediate and high values, indicating fertility of the combination. A pollen viability lower than $50 \%$ can result from a lack of chromosome homology, probably, due to the genetic distance between species, or due to the presence of heterozygous translocations or due to the presence of cytoplasmic male sterility genes. These combinations should be carefully analyzed to isolate and study the nature and inheritance of male sterility genes, an interesting feature that can be used in breeding programs targeting hybrid production (Pickersgill 1997).

In conclusion, some combinations are possible and fertile, enabling the gene transference between species, whereas the fertility degree of other combinations can differ, indicating partial or complete male sterility, assessed here based on the pollen viability. The conclusion was also drawn that infertility is a postfertilization barrier since the establishment of hybrid combinations is possible, but breeders will have to apply strategies as described by Yoon et al. (2006), to continue the breeding program of Capsicum.

\section{ACKNOWLEDGEMENTS}

The authors thank the Research Foundation of the State of Rio de Janeiro - FAPERJ and the National Council of Scientific and Technological Development-CNPq. 


\title{
Caracterização reprodutiva de híbridos interespecíficos obtidos entre espécies de Capsicum
}

\begin{abstract}
RESUMO - O presente trabalho objetivou fazer a caracterização reprodutiva de híbridos interespecíficos bem como de acessos de Capsicum, via viabilidade polínica. Os híbridos foram obtidos entre espécies de Capsicum. A maioria dos acessos mostrou alta viabilidade polínica, indicando que a meiose é normal resultando em grãos de pólen viáveis. Entre as espécies, C. pubescens apresentou o menor valor de viabilidade polínica $(27 \%)$. Os híbridos interespecíficos apresentaram graus de viabilidade polínica variando desde combinações férteis (C. chinense $x \mathrm{C}$. frutescens $e \mathrm{C}$. annuum $x \mathrm{C}$. baccatum) a combinações macho estéreis. A viabilidade polínica também variou dentro da combinação hibrida dependendo dos acessos usados no cruzamento. Os resultados indicam que a macho esterilidade é uma das barreiras de incongruidade observadas entre espécies de Capsicum uma vez que é possível se obter o híbrido, mas ele pode ser macho estéril.
\end{abstract}

Palavras-chave: Capsicum, espécies silvestres, espécies domesticadas, grão de pólen, macho esterilidade.

\section{REFERENCES}

Alexander MP (1969) Differential staining of aborted and nonaborted pollen. Stain Technology 44: 117-122.

Bapa Rao N, Sri Valli T and Lakshmi N (1992) Cytogenetic studies on the interspecific hybrid Capsicum baccatum L. - C. frutescens L. and its progeny. Euphytica 59: 135-140.

Carputo D (1999) Post-zygotic gametic selection due to endosperm balance number explains unusual chromosome numbers of $3 \mathrm{x} \times$ $2 x$ progeny in Solanum. Sexual Plant Reproduction 12: 27-31.

Costa FR, Pereira TNS, Vitória AP, Campos KP, Rodrigues R, Silva DH and Pereira MG (2006) Genetic diversity among Capsicum accessions using RAPD markers. Crop Breeding and Applied Biotechnology 6: 18-23.

Cruz CD (2001) Programa Genes (Versão Windows): aplicativo computacional em genética e estatística. UFV, Viçosa, 648p.

Dafni A (1992) Pollination ecology - a practical approach Oxford University Press, New York, 250p.

Egawa Y and Tanaka C (1986) Cytogenetical study of the interspecific hybrid between Capsicum anиum and C. baccatum. Japanese Journal of Breeding 36: 16-21.

Filgueira FAR (2003) Novo manual de olericultura: agrotecnologia moderna na produção e comercialização de hortaliças. UFV, Viçosa. 412p.

Hajjar R and Hodgkin T (2007) The use of wild relatives in crop improvement: a survey of developments over the last 20 years. Euphytica 156: 1-13.

Hogenboom NG (1973) A model for incongruity in intimate partner relationships. Euphytica 22: 219-233.
Kumar AO, Panda RC and Raja RKG (1987) Cytogenetic studies of the hybrids of Capsicum annuum with $C$. chinense and $C$. baccatum. Theoretical and Applied Genetics 74: 242-246.

Lanteri S and Pickersgill B (1993) Chromosomal structural changes in Capsicum annuum L. and C. chinense Jacq. Euphytica 67: 155-160.

Moscone EA, Scandaferro MA, Grabiele M, Cecchini NM, Garcia YS, Jarret R, Daviña JR, Ducasse DA, Barboza GE and Ehrendorfer F (2007) The evolution of chili peppers (Capsicum - Solanaceae): a cytogenetic perspective. Acta Horticulture 745: 137-169.

Onus AN and Pickersgill B (2004) Unilateral incompatibility in Capsicum (Solanaceae): occurrence and taxonomic distribution. Annals of Botany 94: 289-295.

Panda RC, Kumar OA and Raja Rao KG (1987) Desynaptic mutant in chili pepper. Journal of Heredity 78: 101-104.

Pickersgill B (1997) Genetic resources and breeding of Capsicum spp. Euphytica 96: 129-133.

Pickersgill B (2007) Domestication of plants in the Americas: insights from Mendelian and molecular genetics. Annals of Botany 100: 925-940.

Pozzobon MT and Schifino-Wittmann MT (2006) A meiotic study of the wild and semi-domesticated Brazilian species of genus Capsicum L. (Solonaceae). Cytologia 71: 275-287.

Pozzobon MT, Schifino-Wittmann MT and Bianchetti LB (2006) Chromosome numbers in wild and semidomesticated Brazilian Capsicum L. (Solonaceae) species: do $\mathrm{x}=12$ and $\mathrm{x}=13$ represent two evolutionary lines? Botanical Journal of the Linnean Society 151:259-269

Crop Breeding and Applied Biotechnology 11: 241-249, 2011 
Reproductive characterization of interspecific hybrids among Capsicum species

Ryzhova NN and Kochieva EZ (2004) Analysis of microsatellite loci of the chloroplast genome in the genus Capsicum (pepper). Russian Journal of Genetics 40: 892-896

Shifriss C (1997) Male sterility in pepper (Capsicum аппиит L.) Euphytica 93: 83-88.

Singh RJ (1993) Plant cytogenetics. CRC Press, Boca Raton, $391 \mathrm{p}$.
Tanskley SD (1984) High rates of cross-pollination in chile pepper. HortScience 19: 580-582.

Yoon JB, Yang DC, Do JW and Park HG (2006) Overcoming two post-fertilization genetic barriers in interspecific hybridization between Capsicum annuum and C. baccatum for introgression of anthracnose. Breeding Science 56: 31-38. 